\title{
IMPROVING BUSINESS PROCESSES BY USING LARAVEL ON THE NEW STUDENT REGISTRATION SYSTEM OF SD MARSUDIRINI GEDANGAN SEMARANG
}

\author{
Eko Budy Karuniawan ${ }^{1}$, Rama Agastya1, Visca Anggrainy ${ }^{1}$, Dina Fitria Murad ${ }^{1}$, Teguh Prasandy ${ }^{1 *}$, \\ Melania Wianastiti², And Titan² \\ ${ }^{1}$ Information Systems Department, Binus Online Learning, Bina Nusantara University \\ ${ }^{2}$ Language Center Department, Bina Nusantara University \\ E-mail: teguh.prasandy@binus.edu
}

\begin{abstract}
During the COVID-19 pandemic, the delta variant was pretty crazy with high deaths, high transmission and increasing cases, so the government pulled the emergency brake in the form of emergency PPKM. Emergency PPKM up to PPKM level 1-4 where education is still 100\% working from home. So that new student registration activities should be carried out using internet media and web-based applications. For prospective students who will enroll in the school, it can make it easier for them to register online, the registration menu is still in the form of uploading files. One of the PHP frameworks often recommended by PHP programming forums is the Laravel framework. So that the process of developing the registration information system of Marsudirini Elementary School uses the Laravel Framework. Considering the development of the web-based programming world with the emergence of the PHP Framework, the system development method also adapts to the concept of the PHP Framework, where the basis of the PHP Framework is Object Oriented Programming (OOP) PHP. Then the application development for SD Marsudirini Gedangan Semarang school registration system uses the Scrum method. The need for a registration information system consists of 2 business processes, namely the registration process and the admission process for new students, where the entire process will be a reporting to stakeholders. With the use of the Laravel framework, there is an improvement in the process of registering and uploading files, as well as verifying files by the registration administration.
\end{abstract}

Keywords: Laravel, Student Registration, SD Marsudirini Gedangan Semarang

\section{BACKGROUND}

During the COVID-19 pandemic, the delta variant was pretty crazy with high deaths, high transmission and increasing cases, so the government pulled the emergency brake in the form of emergency PPKM. Emergency PPKM up to PPKM level 1-4 where education is still $100 \%$ working from home. So that new student registration activities should be carried out using internet media and web-based applications.

Marsudirini Gedangan Elementary School Semarang has already created a web profile at the end of 2020 at the address SDMarsudirinigedangan.sch.id, according to (M. Abdul Jabbar, Rika Puspita, 2017) to convey information about schools to the wider community via the Internet. In addition, for prospective students who will enroll in the school, it can make it easier for them to register online, the registration menu is still in the form of uploading files, it can be seen in figure 1 .

By using file uploads, it has met the PPKM emergency recommendations up to PPKM levels 1-4, but still has weaknesses such as the possibility of duplicate data occurring because students twice upload, the accuracy level in document checking is missing in the registration section, incomplete files cannot go through other channels. , and the maximum file restrictions and file types to upload. Some of these issues can be overcome by using an integrated and systematic archiving system so that the new Student Administration can view the files in the applicant's name, if any files are missing, the registrants simply upload the missing files, and the Admissions Administration department just checks on

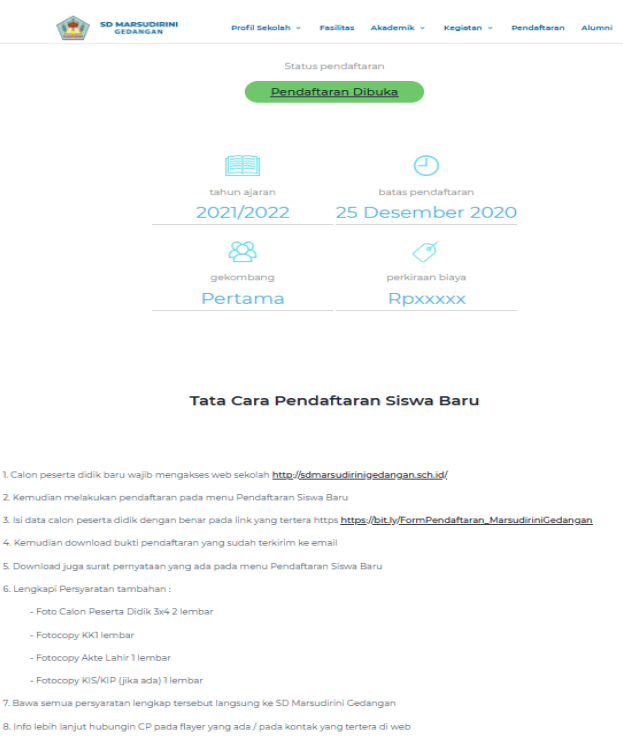

Figure 1. New Student Registration Menu Display

shortcomings. . In addition to information about the file, parents can also track the progress of student admissions at school online without having to come to school. According to (Mursyidah et al., 2021) PPDB Online is a service innovation in education. According to (Astuti \& Syaputra, 2020) new student registration is a set of data processing activities that play an important role in supporting the main activities of educational institutions in the context of conducting the teaching process, while this activity is related to the new student registration process and announcements of new students accepted. From these issues, it can be concluded that schools need an online registration application (web-based application) that can 
be accessed by the registration administration, parents, principals and other interested parties in Marsudirini Gedangan Elementary School, Semarang.

According to (Wijonarko \& Budi, 2019) this system is built on a web platform so that it can be accessed by users anywhere, anytime, as long as it is connected to an internet connection. The display of this system can also adapt to mobile devices, so that users can also access through Internet browsers on their respective mobile devices, because the system display already has a "Responsive User Interface" function. The hope and purpose of building a new student registration system at Malang City Polytechnic is that the registration and management process can be well recorded and potential registrants can get registration information quickly and accurately. According to (Firma Sahrul B, 2017) Academic Information System Development makes using a framework very easy for developers. One of the frameworks that is still relatively new in creating webbased information systems is Laravel. The use of Laravel is expected to facilitate the establishment of an Academic Information System, thereby increasing the quality of a school institution. Building a web-based system can use multiple programming languages such as Java, ASP, and PHP. Out of the three PHP programming languages, which are preferred by web programmers because they are based on open source, several have communities and frameworks. One of the PHP frameworks often recommended by PHP programming forums is the Laravel framework. So that the process of developing the registration information system of Marsudirini Elementary School uses the Laravel Framework.

The goal of this study is to analyze the need for a new student registration system at Marsudirini Gedangan Elementary School, Semarang, to improve business processes by using the Laravel framework in the new student registration system at Marsudirini Gedangan Elementary School, Semarang.

\section{METHOD}

Considering the development of the web-based programming world with the emergence of the PHP Framework, the system development method also adapts to the concept of the PHP Framework, where the basis of the PHP Framework is Object Oriented Programming (OOP) PHP. Then the application development for SD Marsudirini Gedangan Semarang school registration system uses the Scrum method out (Roger S. Pressman \& Bruce R. Maxim, 2015) the method can be seen in Figure 2.

Starting with the creation of a product backlog, with each product backlog being prioritized upon its completion. Each product backlog is then divided into several sprints, which are completed by each person according to their assignment and completion schedule. Scrum is well suited when using a programming language framework because the documentation in the programming language framework is very well documented and easy to read for programmers who will be re-developing. Each sprint backlog is completed between 2-3 weeks where the sprint consists of several steps completed in the form of hours between 6-12 hours. More focus on microscale programming and implementation documentation. After a sprint backlog is completed, a sprint review is conducted. After the sprint assessment is completed, the sprint backlog process continues, and so on until the entire sprint backlog is completed and the new student registration information system is implemented.

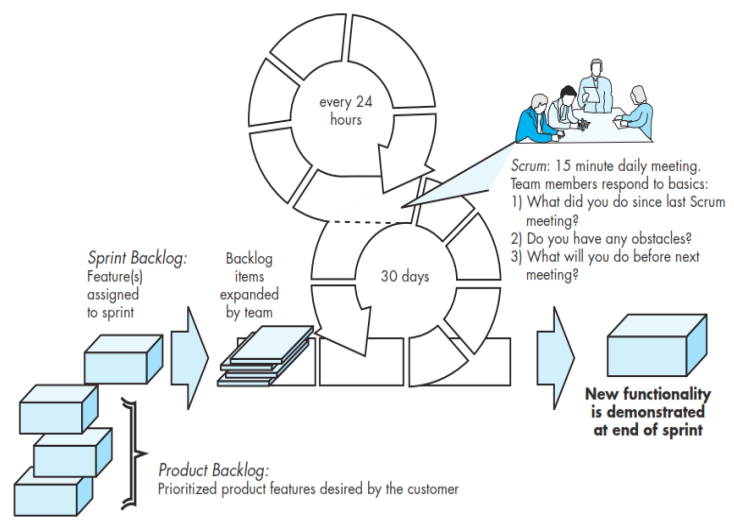

Figure 2. Scrum method

(source (Roger S. Pressman \& Bruce R. Maxim, 2015))

\section{RESULTS AND DISCUSSION}

1. Meeting the online registration system require-ments for SD Marsudirini Gedangan Semarang, can be seen in Figure 3.

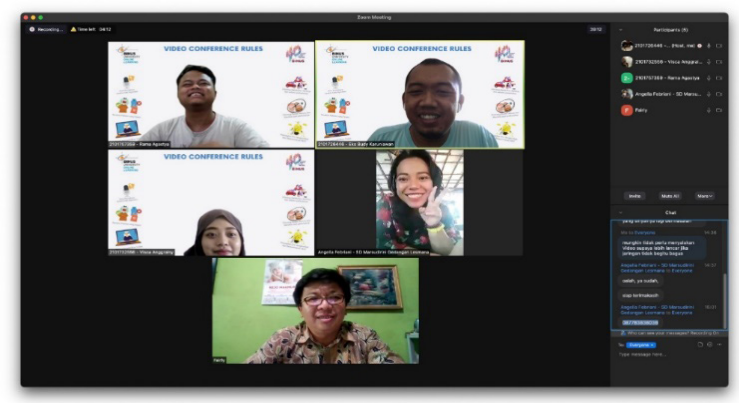

Figure 3. Responding to the need for the online registration system between development team and school parties

During the meeting, some business processes for school registration and functions that schools need were produced.

2. Main Business Process in School Enrollment

The business process for school registration can be seen in Figure 4.
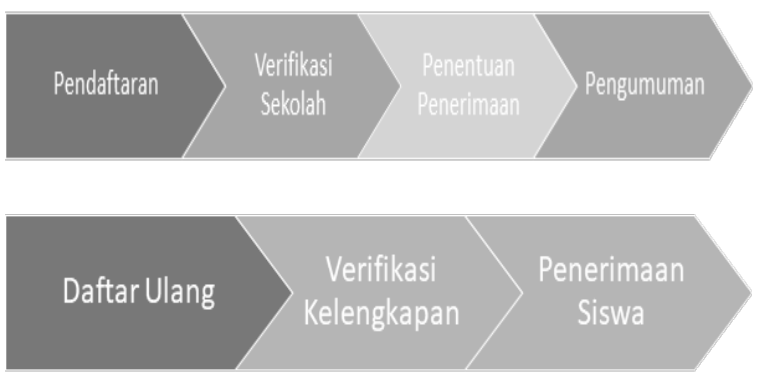

Figure 4. School Registration Business Process 
The business process is divided into 2 main processes, process 1 is the registration process and process 2 is the re-registration process.

3. Student Registration Business Process

The business process of student registration can be seen in Figure 5.

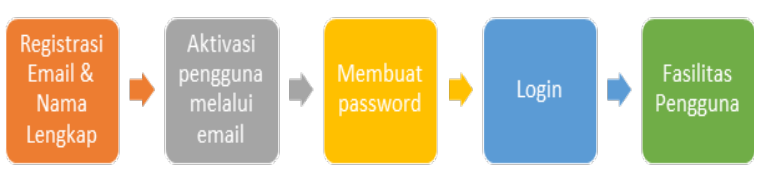

Figure 5. Student Registration Business Process

Regarding the need for application design adjustments, all application screenshots in this paper are in Indonesian. The business process starts with registering the student's email address and full name, then activating the user via email, creating a password and logging in. This process is an improvement over the previous process. In addition to improving the process, there is also a user safety safeguard with activation sent via email so that not all registrant accounts are activated immediately, but have to go to the registrant's email via a link. This is used to protect irresponsible registered users. This can be seen in figure 6 .

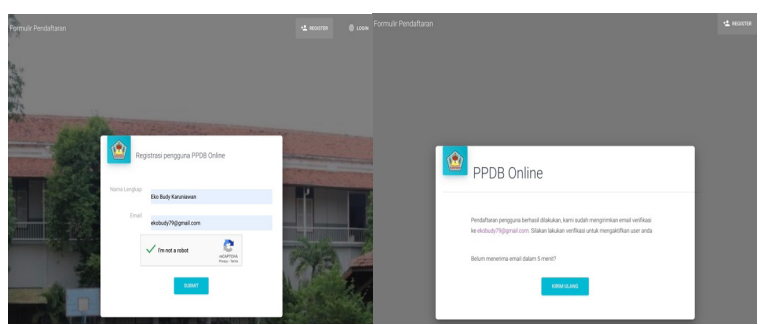

Figure 6. Student Registration Form

In addition to the email in the email, a captcha is given so that users in the form of robots cannot register. The system will send a verification email with a verification link, where the registrant must activate it via the link, and the user will be prompted to set a password, as illustrated in Figure 7:

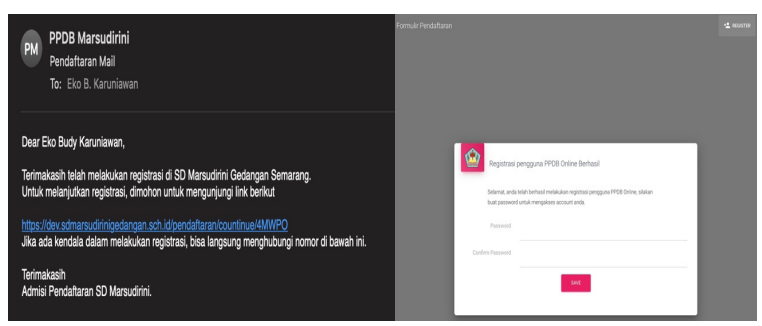

Figure 7. Set Activation Email and Password

After setting the password, the user can login, which is illustrated in Figure 8:

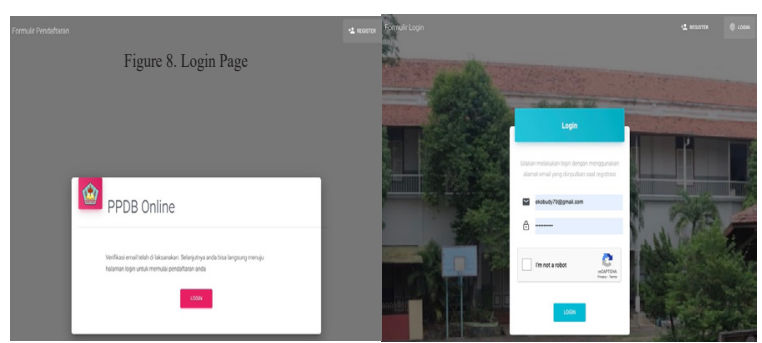

Figure 8. Login Page
Furthermore, registrants can complete the registration form and upload the necessary documents. The registration form is designed using a wizard model so that it is easier for users to operate and perform better when using a mobile device. The format of the registration form is as follows:

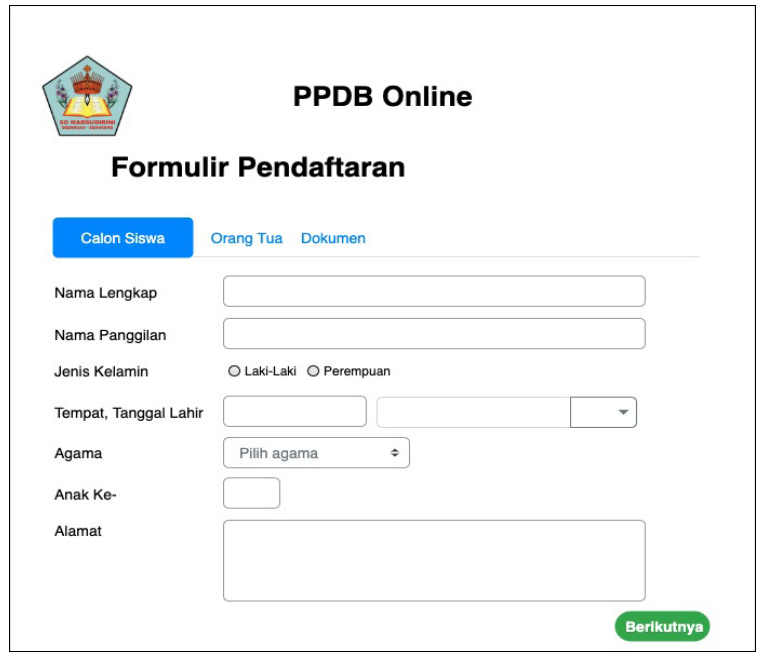

Figure 9. Design Form Student Registration

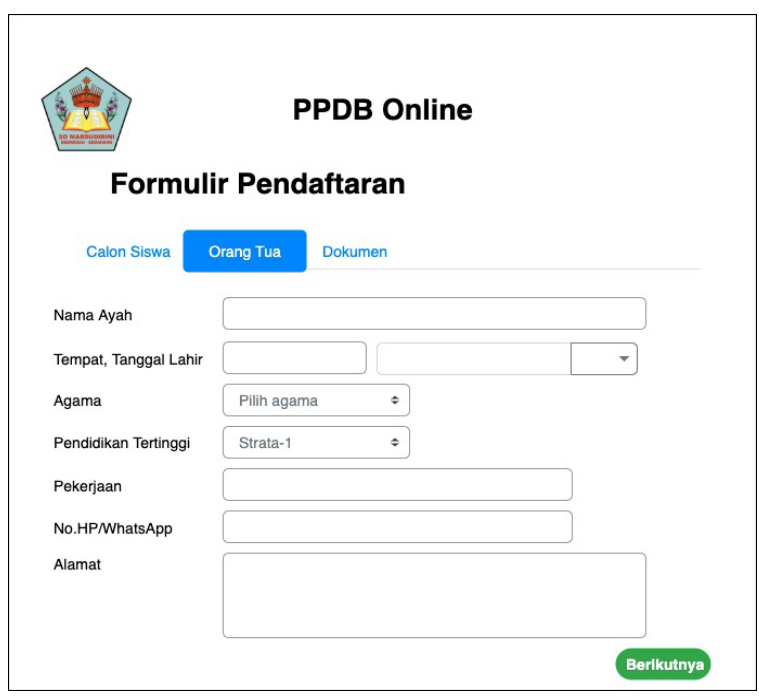

Figure 10. Design Form Student Parent

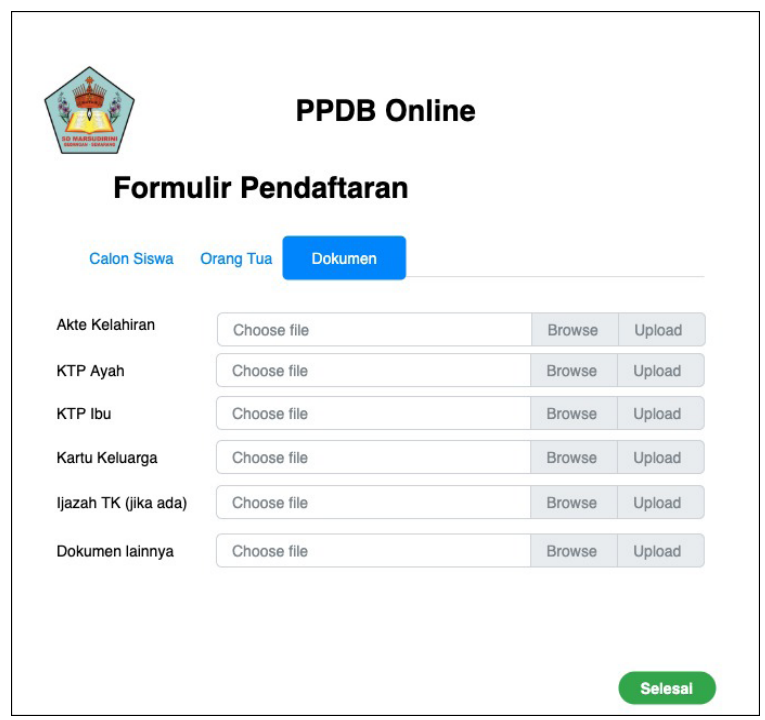

Figure 11. Design Form upload document 


\section{4. school verification}

After all enrollment files have been uploaded by the enrollee, in this case the prospective student, the Registration Administration Department validates and processes the enrollment file uploaded by the prospective student. The business process for verification can be seen in Figure 12.

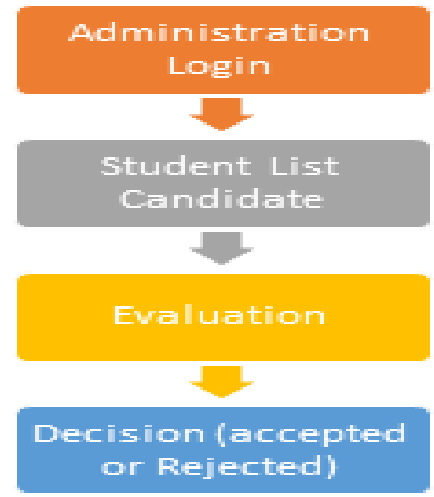

\section{Figure 12. Student Verification Process}

During the validation process, the admission is presented with a display like the following:

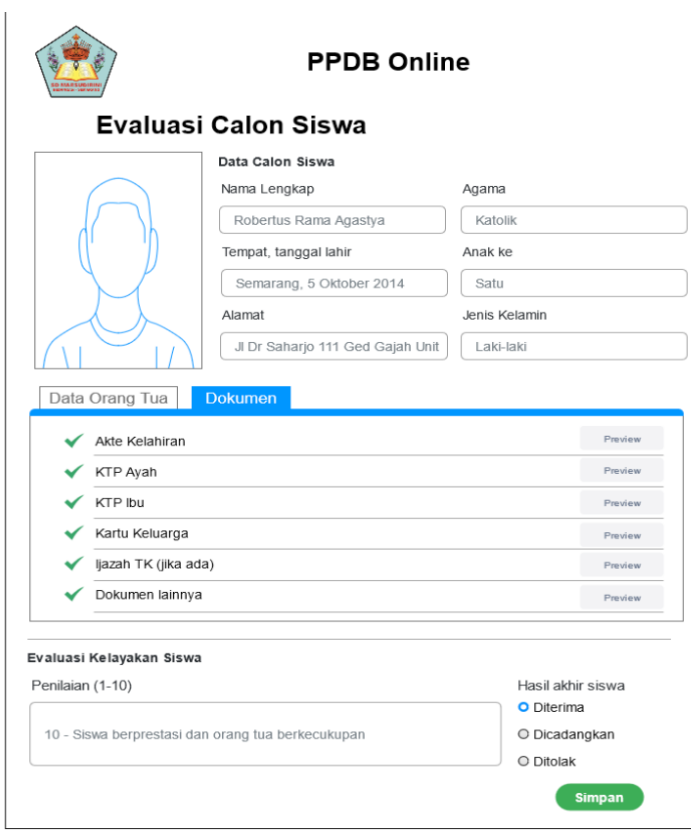

\section{Figure 13. Student Verification Process}

Inside, there is a full view of each section ranging from prospective student data, parent data, to the completeness of the documents attached to PPDB Online. Then proceed to the student eligibility evaluation, where admission includes a rating from 1 10. And ending with the final results of students, there are 3 choices, which is to be accepted as a student at SD Marsudirini Gedangan, to be reserved as a reserve participant if there are students who are accepted who withdraw, and those who are accepted as students who withdraw, the last one is rejected.

5. Business Process Acceptance Announcement The process for announcing students can be seen in Figure 89.

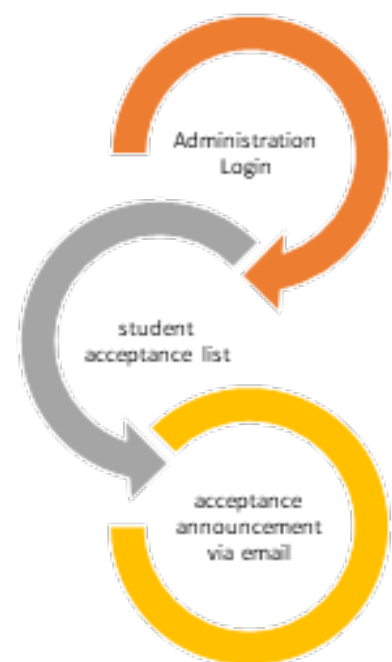

Figure 14. Admission Notice

From this process, the enrollment administration first logs in, then the administrator announces the graduating students via email broadcast based on the list of graduating students. Can see at figure 15 and 16 .

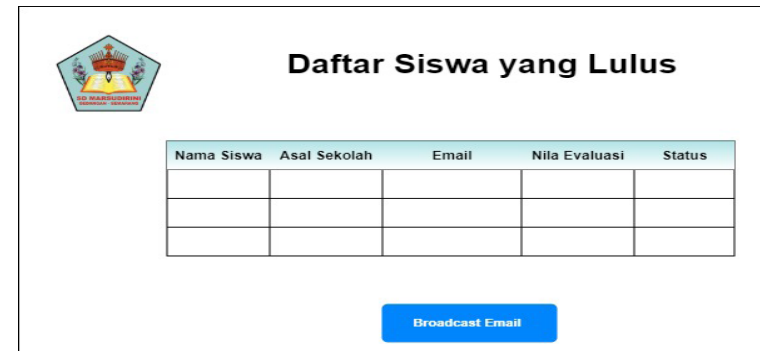

Figure 15. Design of the display list of graduate students

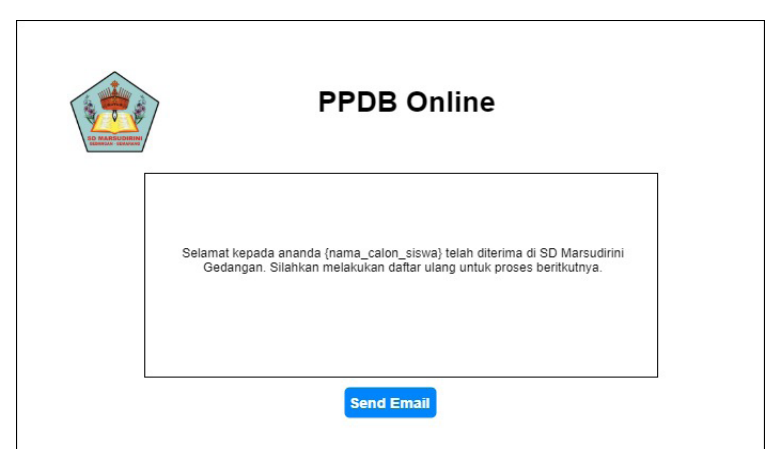

Figure 16. Process for Broadcasting Announcements by Email

6. business process re-registration

The business process for re-registration can be seen in Figure 17.

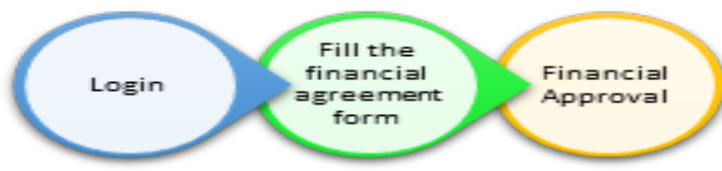

Figure 17. Business Process for Re-enrollment of Accepted Students

After the student is accepted, the status will be updated that the applicant has been accepted into Marsudirini Gedangan Elementary School, Semarang. After the registrant has applied, prospective students will be 
asked to complete a statement committing themselves to participate in teaching and learning activities that take place at the school. After declaring eligibility, the prospective student agrees to the full school entrance fee.

7. Business Process for School Verification and Admission of New Students

the business process of school verification and admission of new students can be seen in figure 18 .

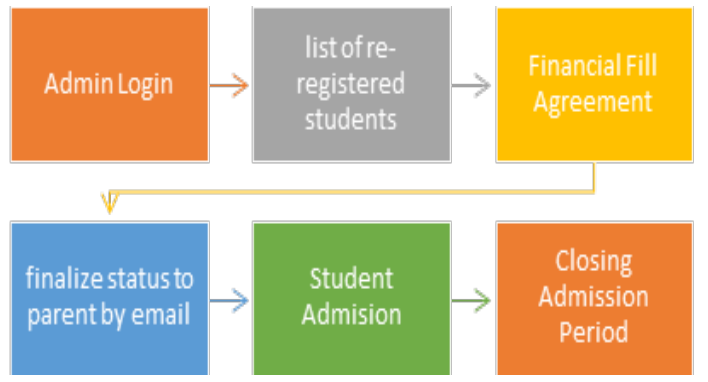

Figure 18. Business Process for School Verification and Admission of New Students

After the prospective student has completed the acceptance file, the school will verify the prospective student file until it is declared accepted. Then all online student enrollment activities will be declared complete.

8. business processes of stakeholders (stakeholders)

The business processes of the stakeholders can be seen in Figure 19.
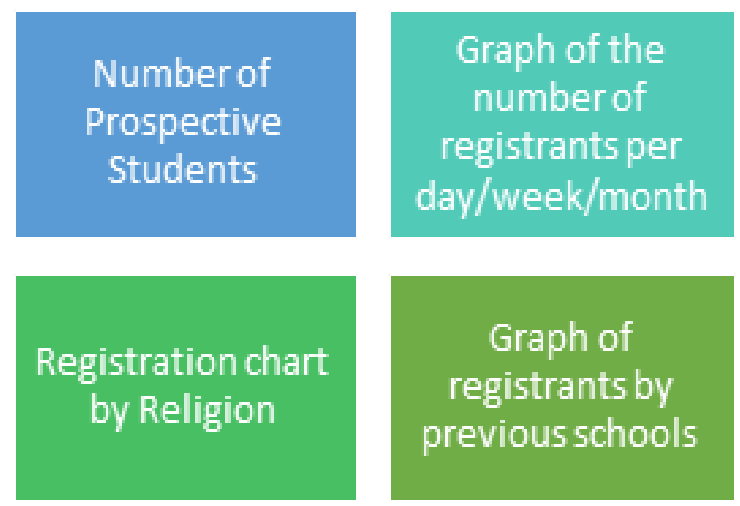

Figure 19. Dashboard for Stakeholder

Those interested can check the reporting of the new student admission process from opening to closing. This information shows how the development of the Marsudirini Gedangan Elementary School in Semarang. So that these parties can determine future policy strategies with regard to the strategy of new pupil admissions in schools.

\section{DISCUSSION}

By using the Scrum method as a system development method and the Laravel framework in developing the registration system for SD Marsudirini Gedangan Semarang, there have been many improvements in business processes so far. Previously, the file was uploaded to the google form, then waited for accumulation and then the file was checked until all acceptance files were checked until announced, so the possibility of tangled files or lost files could occur. By using the new registration system, this possibility is rare because every registration file is in accordance with the registrant's account, the administration only needs to see the existing registrant files according to their account. If the file is incomplete, the holder can complete it directly on his account. When the file is complete, the new administration can check the registration file.

If the registrant is accepted, the registration administration no longer needs to send emails one by one, you can directly blow the email through the registration system. So that the registration administration does not get tired of mailing one by one to prospective students who have been declared accepted. After aspiring students are accepted, they can immediately fill out the student admission file. When all files are complete, the prospective student can be declared a new student at the school.

After the complete acceptance process, the school can close the new student registration period via the system. In addition to closing the systemized student registration, stakeholders in this case can also allow school stakeholders to monitor the process that is taking place and make it easier to get reports on new student admissions. So that stakeholders can make policy decisions for the future development of SD Marsudirini Gedangan.

\section{CONCLUSSION}

1. The need for a registration information system consists of 2 business processes, namely the registration process and the admission process for new students, where the entire process will be a reporting to stakeholders.

2. With the use of the Laravel framework, there is an improvement in the process of registering and uploading files, as well as verifying files by the registration administration.

\section{ACKNOWLEDGMENT}

We would like to thank the community development of Bina Nusantara University which has facilitated community service activities. We express our deepest gratitude to SD Marsudirini Gedangan Semarang and Binus Online Learning students for the developing the system. This community service can run smoothly thanks to the full support from the leadership of Binus Online Learning..

\section{REFERENCES}

Astuti, M. P., \& Syaputra, H. (2020). Sistem Informasi Penerimaan Siswa Baru (PSB) Online Pada Smk Negeri 1 Air Kumbang. Bina Darma Conference on Computer Science, 22-29.

Firma Sahrul B, M. A. S. O. D. W. (2017). Implementasi Sistem Informasi Akademik Berbasis Web Menggunakan Framework Laravel. Jurnal Transformasi, 12(1), 1-4. 
M. Abdul Jabbar, Rika Puspita, H. I. (2017). Sistem Informasi Pendaftaran Siswa Baru. Jurnal Ekonomi Volume 18, Nomor 1 Maret201, 2(1), 41-49.

Mursyidah, L., Rodiyah, I., \& Ramadhan, H. A. I. (2021). PPDB Online As Innovation of Education Services. Journal of Physics: Conference Series, 1764(1). https://doi.org/10.1088/1742-6596/1764/1/012074
Roger S. Pressman, P. D., \& Bruce R. Maxim, P. D. (2015). Software engineering: a practitioner's approach (8th editio). McGraw-Hill Education.

Wijonarko, D., \& Budi, F. W. S. (2019). Implementasi Framework Laravel Dalam Sistem Pendaftaran Mahasiswa Baru Politeknik Kota Malang. Jurnal Informatika Dan Rekayasa Elektronik, 2(2), 35. https://doi.org/10.36595/jire.v2i2.116 